\title{
Pelatihan Kontrol Keuangan UMKM di Masa Pandemi menggunakan Media Daring Googlemeet William Wendy Ary ${ }^{1}$ \\ ${ }^{1}$ Institut Shanti Bhuana \\ Email: william.wendy@shantibhuana.ac.id ${ }^{1 *}$ \\ *Corresponding author: william.wendy@shantibhuana.ac.id ${ }^{1}$
}

\begin{abstract}
ABSTRAK
Kemunculan virus covid-19 telah menyebabkan goncangan di seluruh aspek kehidupan manusia salah satunya adalah perekonomian. Salah satu sektor perekonomian yang merasakan dari dampak pandemi covid-19 ini adalah sektor UMKM. Sektor UMKM berkontribusi hampir lebih dari 57,8\% perekonomian bagi perekonomian Indonesia dan apabila sektor ini tergoncang maka perekonomian Indonesia otomatis akan ikut tergoncang. Hal inilah yang melatarbelakangi pelaksanaan pengabdian masyarakat tentang kontrol keuangan UMKM di masa pandemi. Pelaksanaan pengabdian ini berbentuk Webinar yang terdiri dari dua sesi acara yaitu sesi pemaparan materi selama 90 menit dan sesi pelatihan selama 30 menit. Kegiatan pengabdian masyarakat ini dirasakan manfaatnya oleh para peserta yang berasal dari pelaku UMKM sampai Mahasiswa, kegiatan ini juga memperoleh penilaian angka kepuasan yang cukup tinggi terhadap pelaksanaan kegiatan dan peserta juga memiliki tingkat pemahaman terhadap materi yang disampaikan di kisaran angka $76-100 \%$.
\end{abstract}

Kata Kunci: UMKM, Keuangan, Pandemi, Manajemen, Pengabdian Masyarakat

\section{UMKM Financial Control Training during a Pandemic using Online Media Googlemeet}

\begin{abstract}
The emergence of covid-19 virus has caused shocks in all aspects of human', one of which is world's economy. One of the economic sectors that is affected by covid-19 pandemic is the MSME sector. The MSME sector contributes almost more than 57,8\% of the economy of Indonesia and if this sector is unstable then the Indonesian economy will automatically be in trouble. This problem has encouraged this community service activity to educate the owners of MSME to manage their business properly during the pandemic. The activities consist of two event sessions in a webinar: a 90-minute material exposure session and a 30-minute training session. These community service activities not only benefits all the participants, but also gets high satisfaction ratings. Furthermore, the participants mostly said that they have around $76-100 \%$ level of understanding after they attended this community service webinar.
\end{abstract}

Keywords: MSME, Finance, Pandemic, Management, Community Service 


\section{PENDAHULUAN}

Pandemi covid-19 telah menyebabkan goncangan yang hebat pada seluruh sektor kehidupan yang ada di dunia dan sektor perekonomian pun merasakan dampak dari pandemi tersebut tidak terkecuali sektor Usaha Mikro Kecil dan Menengah (UMKM). Sektor UMKM memberikan kontribusi yang sangat besar bagi perekonomian di Indonesia dimana 57,8\% sumber Pendapatan Domestik Bruto (PDB) Indonesia berasal dari sektor UMKM (Kementerian Koperasi dan Usaha Kecil dan Menengah, 2018). Kontribusi terhadap perekonomian yang besar ini tentu saja membuat perekonomian Indonesia sangat bergantung pada UMKM dan apabila UMKM mengalami goncangan tentu akan berdampak negatif terhadap perekonomian secara makro maupun mikro. Selain itu, UMKM juga dapat berkontribusi untuk mengurangi angka kemiskinan (Yoka Roida, Sunarjanto, \& Jayaprana, 2010)

Namun, dibalik kontribusi dan pengaruhnya yang besar terhadap perekonomian di Indonesia, UMKM masih dipandang sebelah mata oleh masyarakat pada umumnya. Hal ini cukup wajar karena mayoritas aktivitas para pelaku di sektor ini masih tidak terlalu besar dibanding aktivitas pada sektor yang lainnya yang berbentuk korporasi. Selain dari aktivitas bisnis, permasalahan yang sering ditemui dari para pelaku UMKM terutama di Indonesia adalah dari segi keuangan. Permasalahan ini bahkan sudah menjadi permasalahan yang cukup klasik dan menjadi perhatian yang sangat serius baik dari kalangan pemerintah sampai akademisi.

Salah satu permasalahan keuangan yang ditemukan di UMKM adalah masalah perilaku pengelolaan keuangan yang berkaitan dengan pengetahuan keuangan yang dimiliki (Bartz \& Winkler, 2016; Humaira \& Sagoro, 2018). Permasalahan ini tentu tidaklah mengherankan apabila UMKM selalu menghadapi kesulitan dalam akses pendanaan, masalah operasional dan adminstrasi serta masalah tingkat penjualan (Hadiyati \& Mulyono, 2017; Naidu \& Chand, 2012)

Berangkat dari permasalahan tersebut maka pendampingan kepada pelaku UMKM perlu dilaksanakan untuk membantu para pelaku UMKM agar bisa bertahan di masa pandemi covid-19 ini terutama yang berkaitan dengan pengelolaan keuangan. Pendampingan keuangan ini perlu untuk menaikkan taraf akuntabilitas dan pengelolaannya supaya dapat dipertanggung jawabkan layaknya sebuah korporasi besar (Aribawa, 2016)

Berdasarkan hasil identifikasi awal yang dilakukan oleh peneliti terhadap beberapa pelaku UMKM di Kota Bengkayang, maka peneliti menyimpulkan bahwa perlu dilaksanakan pelatihan kontrol keuangan kepada pelaku UMKM. Tujuan dari dilaksanakannya pengabdian masyarakat ini adalah 
untuk memberikan wawasan kepada pelaku UMKM mengenai pengelolaan dasar keuangan dan memberikan beberapa masukan masukan keuangan praktis yang dapat digunakan supaya pelaku UMKM dapat bertahan di masa pandemi covid-19.

Kontrol keuangan merupakan suatu topik yang sampai saat ini masih terus mendapatkan perhatian. Setidaknya ada empat faktor kontrol keuangan yang menentukan kapabilitas suatu bisnis yaitu 1) mengawasi masalah keuangan, 2) merencanakan masa depan, 3) memilih produk keuangan dengan bijak, dan 4) mencari informasi (Atkinson, McKay, Kempson, \& Collard, 2006). Bialowolski, WeziakBialowolska, \& McNeely (2021) menemukan bahwa sebuah institusi yang memiliki kontrol keuangan yang baik cenderung melindungi dan berperan sebagai tameng yang membantu bisnis untuk bertahan. Porras-Gómez (2020) mengajukan sebuah konsep mekanisme kontrol yang diperlukan dalam sebuah organisasi yang disebut dengan piramida kontrol (lihat gambar 1).

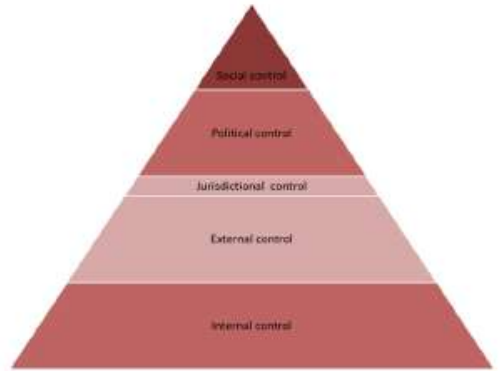

Gambar 1. Piramida Kontrol PorrasGómez, 2018
Piramida tersebut terdiri dari lima tingkatan kontrol organisasi yang terdiri dari kontrol internal (tingkat pertama), kontrol eksternal (tingkat kedua), kontrol yurisdiksi (tingkat ketiga), kontrol politik (tingkat keempat) dan kontrol sosial (tingkat kelima). UMKM sebagai salah satu organisasi yang berhadapan dengan eksposur dari kelima unsur yang ada dalam piramida ini, tentu saja perlu untuk beradaptasi ditengah masa krisis seperti pandemi covid-19 ini.

\section{METODE PENELITIAN}

Adopsi peranan media Teknologi Informasi (TI) di masa pandemi covid-19 untuk melaksanakan tugas tridharma merupakan sebuah keharusan sebagai salah satu langkah supaya akademisi tetap bisa melaksanakan tri dharma. Apalagi UMKM saat ini dituntut untuk semakin mengadopsi media TI dalam aktivitas usahanya. Media TI memberikan wadah yang bermanfaat bagi UMKM karena menawarkan efektivitas, efisiensi dan memberikan nilai tambah untuk menaikkan daya saing UMKM (Syarifah \& Fauziyah, 2017). Pelaksanaan pengabdian masyarakat ini dilaksanakan dalam bentuk webinar dengan menggunakan media daring googlemeet dengan target peserta adalah sebanyak 100 orang dan link disebarkan melalui pesan berantai media sosial seperti whatsapp, Instagram, facebook maupun line. Pelaksanaan kegitan ini dilaksanakan pada tanggal 15 Juli 2020 dengan melibatkan tiga orang panitia yang merupakan mahasiswa 
Institut Shanti Bhuana Bengkayang.

Dalam webinar ini menggunakan dua metode yaitu dengan metode seminar dan pelatihan singkat.

\section{Metode Seminar}

Seminar adalah suatu bentuk komunikasi verbal yang bersifat ilmiah untuk membahas suatu masalah yang menyangkut kepentingan bersama dan mendesak dengan berpijak pada prasaran serta tanggapantanggapan dan diskusi sehingga terumuskan suatu pemecahan yang akurat (Kamdhi, 2003). Seminar ini diberikan kepada para pelaku UMKM yang mendaftar dan diikuti oleh 33 orang yang berasal dari berbagai kalangan baik dari target peserta utama yaitu pelaku UMKM di Kota Bengkayang sampai Mahasiswa yang berasal dari berbagai kampus yang ada di Indonesia. Seminar ini diberikan selama sekitar 90 menit dan peneliti menjadi narasumber pada kegiatan ini dengan memberikan materi yang berjudul "Kontrol Keuangan di Masa Pandemi”.

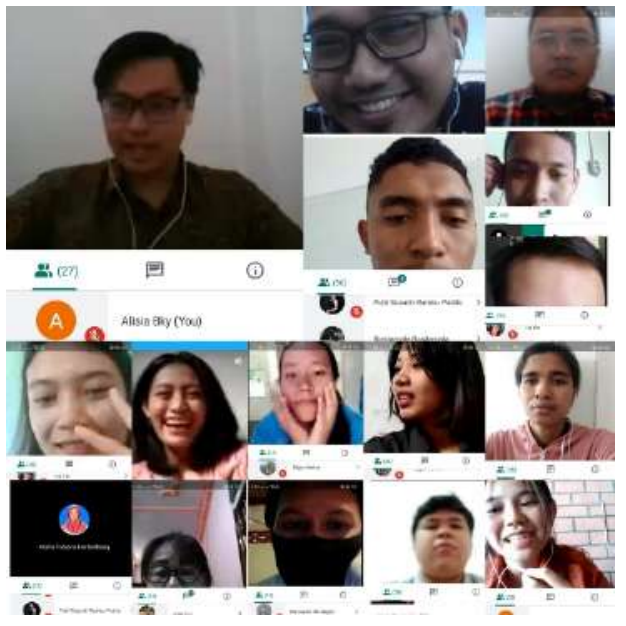

Gambar 2. Screenshot

dokumentasi selama pemaparan materi

\section{Metode Pelatihan Singkat}

Pelatihan adalah suatu proses penyampaian dan pemilikan keterampilan, pengetahuan dan nilai - nilai (Sudjana, 2007). Sesi pelatihan ini dilaksanakan ketika sesi seminar sudah selesai dilaksanakan dan waktu pelatihan singkat ini adalah selama 30 menit. Peserta diminta untuk mengerjakan latihan sederhana dalam pembuatan laporan arus kas sederhana.

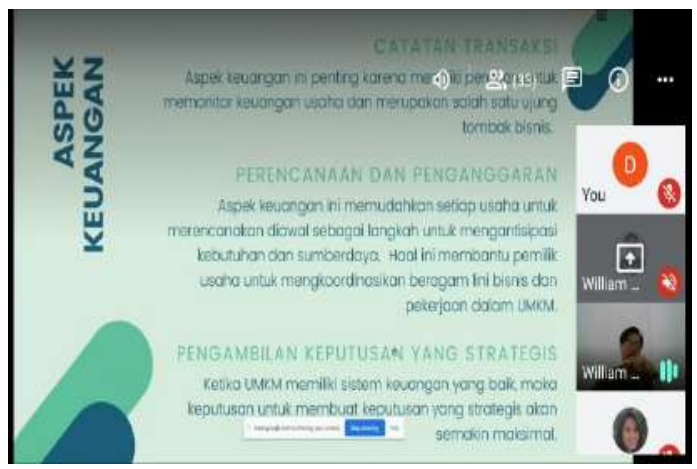

Gambar 3 Sesi Latihan

\section{HASIL DAN PEMBAHASAN}

Hasil dari kegiatan pengabdian masyarakat dalam bentuk webinar pengabdian masyarakat ini dapat dilihat pada tabel 1 berikut. Tabel 1. Hasil kegiatan Pelatihan Kontrol Keuangan di Masa Pandemi

\begin{tabular}{|c|c|c|}
\hline Tujuan & Kegiatan & Luaran \\
\hline $\begin{array}{l}\text { Pemberian } \\
\text { wawasan } \\
\text { kepada } \\
\text { pelaku } \\
\text { UMKM }\end{array}$ & $\begin{array}{l}\text { Webinar } \\
\text { Kontrol } \\
\text { Keuangan } \\
\text { di Masa } \\
\text { Pandemi }\end{array}$ & $\begin{array}{l}\text { Peserta } \\
\text { memahami } \\
\text { pentingnya } \\
\text { memiliki } \\
\text { kontrol } \\
\text { keuangan yang } \\
\text { baik }\end{array}$ \\
\hline
\end{tabular}




\begin{tabular}{|c|c|c|}
\hline Tujuan & Kegiatan & Luaran \\
\hline & & $\begin{array}{l}\text { Peserta } \\
\text { memahami } \\
\text { aspek-aspek } \\
\text { penting dalam } \\
\text { keuangan } \\
\text { UMKM }\end{array}$ \\
\hline & & $\begin{array}{l}\text { Peserta } \\
\text { mengerti cara - } \\
\text { cara untuk } \\
\text { mengelola } \\
\text { usahanya } \\
\text { supaya dapat } \\
\text { bertahan di } \\
\text { masa pandemi } \\
\text { covid-19 }\end{array}$ \\
\hline $\begin{array}{l}\text { Pemberian } \\
\text { beberapa } \\
\text { masukan } \\
\text { praktis } \\
\text { supaya } \\
\text { UMKM } \\
\text { dapat } \\
\text { bertahan }\end{array}$ & $\begin{array}{l}\text { Pelatihan } \\
\text { Singkat }\end{array}$ & $\begin{array}{l}\text { Peserta dapat } \\
\text { mempraktikkan } \\
\text { pembuatan } \\
\text { laporan } \\
\text { keuangan } \\
\text { berupa laporan } \\
\text { arus kas } \\
\text { sederhana. }\end{array}$ \\
\hline
\end{tabular}

Adapun ringkasan dari

kegiatan ini dapat dilihat pada tabel 2 berikut.

Tabel 2 Ringkasan Kegiatan

\begin{tabular}{|c|c|c|}
\hline $\begin{array}{l}\text { Nama } \\
\text { Kegiatan }\end{array}$ & : & 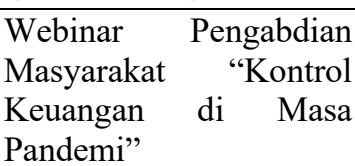 \\
\hline $\begin{array}{l}\text { Pelaksana } \\
\text { Kegiatan }\end{array}$ & : & $\begin{array}{lr}\text { Program } & \text { Studi } \\
\text { Manajemen } & \text { Institut } \\
\text { Shanti Bhuana } & \end{array}$ \\
\hline Tempat & o & Institut Shanti Bhuana \\
\hline Waktu & : & $\begin{array}{l}\text { Rabu, } 15 \text { Juli } 2020 \\
\text { Jam 10:00 }-12: 00\end{array}$ \\
\hline $\begin{array}{l}\text { Jumlah } \\
\text { Pertemuan }\end{array}$ & & 1 kali \\
\hline Biaya & & Gratis \\
\hline
\end{tabular}

Kegiatan pelatihan ini dimulai dengan mengikuti standar pelaksanaan kegiatan seminar secara formal dimana peserta diajak untuk menyanyikan lagu Indonesia Raya, dilanjutkan dengan Kata Sambutan dari Ketua Program Studi Manajemen Institut Shanti Bhuana, Pemaparan Materi Pelatihan dan Latihan Singkat dan ditutup dengan foto bersama peserta. Pelaksanaan kegiatan pengabdian masyarakat ini berjalan lancar dan tepat waktu. Banyak peserta yang antusias dengan kegiatan yang telah dilaksanakan dan hal ini dibuktikan dengan banyaknya peserta yang mengajukan pertanyaan dan dapat juga dijawab dengan baik oleh peneliti. Hal ini dibuktikan dari tingkat kepuasan peserta yang sangat tinggi dimana $45,5 \%$ menyatakan puas dan $54,5 \%$ peserta mengatakan cukup puas dengan pelaksanaan kegiatan (lihat gambar 3).
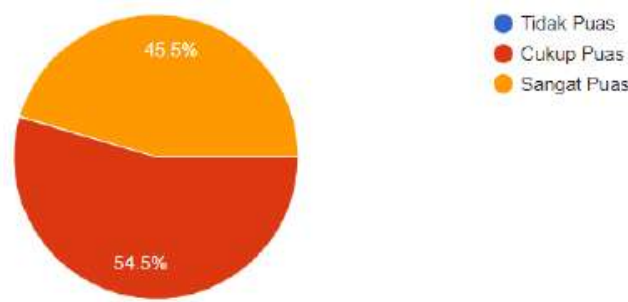

Gambar 4. Grafik tingkat kepuasan terhadap kegiatan pelatihan kontrol keuangan

Selain tingkat kepuasan peserta, kegiatan ini juga sudah langsung dapat dirasakan manfaatnya bagi para peserta dimana 69,7\% peserta mengatakan tingkat pemahamannya sudah mencapai kisaran 76 - 100\%, 24,2\% peserta mengatakan tingkat pemahaman sudah mencapai $50-75 \%$ dan sisanya $6,1 \%$ peserta mengatakan bahwa mereka mengatakan tingkat pemahaman ada dibawah 50\% (lihat gambar 4). 


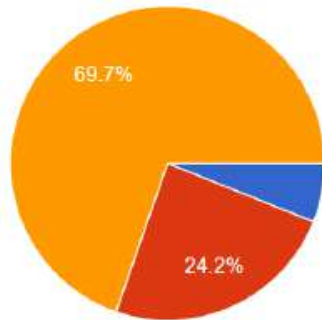

Gambar 5. Grafik Tingkat

Pemahaman Peserta terhadap Materi Pelatihan

Pada saat kegiatan pengabdian masyarakat ini berlangsung cukup terkendali walaupun ada beberapa kendala yang perlu diperbaiki salah satunya adalah masih ditemukan peserta yang tidak mematikan fitur microphone di gadgetnya masing-masing dan solusinya dapat ditangani oleh panitia kegiatan yang menjadi host pengabdian masyarakat ini.

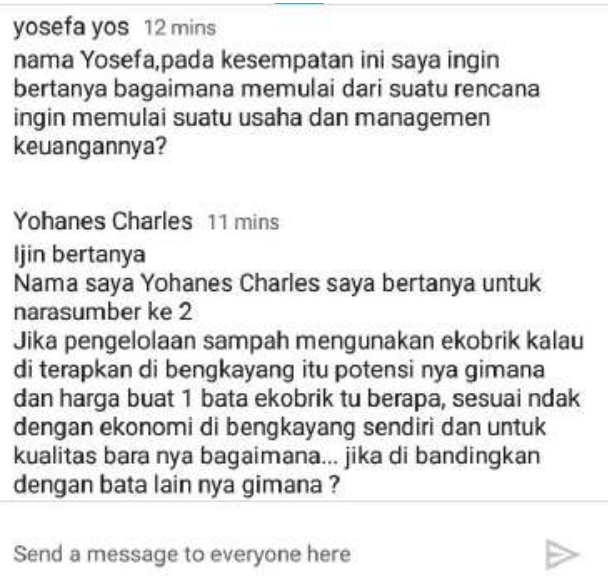

Gambar 6. Sesi Tanya Jawab bersama peserta

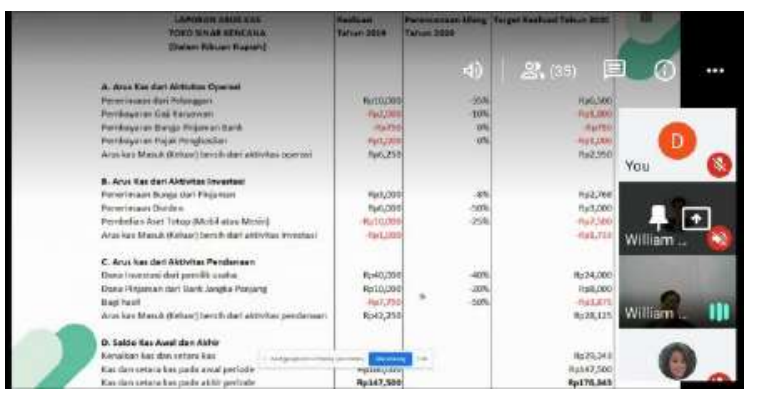

Gambar 7. Sesi Latihan Singkat

Laporan Arus Kas Sederhana

\section{SIMPULAN}

Dari pelaksanaan kegiatan pengabdian kepada masyarakat berbentuk webinar kepada pelaku UMKM ini, maka dapat ditarik beberapa kesimpulan yaitu:

1. Ternyata masih banyak pelaku UMKM terutama pelaku UMKM di Kota Bengkayang yang belum mengetahui cara pengelolaan keuangan yang baik sehingga para peserta yang mengikuti kegiatan pengabdian masyarakat ini mayoritas merasakan manfaat dari terselenggaranya kegiatan ini.

2. Kegiatan pengabdian masyarakat ini mendapatkan respon yang sangat baik dari semua peserta karena sekitar 54,5\% menyatakan cukup puas dan sisanya menyatakan sangat puas

3. Kegiatan pengabdian masyarakat ini juga membuat para peserta mengalami peningkatan pemahaman tentang pengelolaan keuangan UMKM terutama di situasi sulit di tengah masa pandemi ini.

Selain itu, dengan tingkat antusiasme yang sangat tinggi ini juga para peserta menginginkan diadakannya kegiatan yang serupa 
dalam jangka waktu dekat setelah kegiatan terlaksana. Salah satu peserta yang mengatakan bahwa kegiatan selanjutnya peneliti dapat membuat sebuah webinar yang membahas tentang dinamika pasar modal dan investasi.

\section{DAFTAR PUSTAKA}

Aribawa, D. (2016). Pengaruh Literasi Keuangan Terhadap Kinerja dan Keberlangsungan Umkm Di Jawa Tengah. Jurnal Siasat Bisnis, 20(1), 1-13. https://doi.org/dx.doi.org/10.20 885/jsb.vol20.iss 1.art1

Atkinson, A., McKay, S., Kempson, E., \& Collard, S. (2006). Levels of Financial Capability in the UK: results of a baseline survey. UK: financial Services Authority. London, United Kingdom, (March).

Bartz, W., \& Winkler, A. (2016). Flexible or fragile? The growth performance of small and young businesses during the global financial crisis - Evidence from Germany. Journal of Business Venturing, 31(2), 196-215. https://doi.org/10.1016/j.jbusve nt.2015.10.002

Bialowolski, $\quad$ P., WeziakBialowolska, D., \& McNeely, E. (2021). The Role of Financial Fragility and Financial Control for Well-Being. Social Indicators Research, (0123456789). https://doi.org/10.1007/s11205021-02627-5

Hadiyati, E., \& Mulyono, S. (2017). Model of MSME's Competitiveness and Performance Excellent Product in Indonesia: an Approach of Government Policy. International Journal of Business and Social Science, 8(2), 99-108. Retrieved from https://ijbssnet.com/journals/Vo 1_8_No_2_February_2017/13.p $\overline{\mathrm{df}}$

Humaira, I., \& Sagoro, E. M. (2018). Pengaruh Pengetahuan Keuangan, Sikap Keuangan, Dan Kepribadian Terhadap Perilaku Manajemen Keuangan Pada Pelaku Umkm Sentra Kerajinan Batik Kabupaten Bantul. Nominal, Barometer Riset Akuntansi Dan Manajemen, $\quad 7(1)$. https://doi.org/10.21831/nomina 1.v7i1.19363

Kamdhi, J. (2003). Terampil Berargumentasi- Bahasa Dan Sastra Indonesia SMA MA Kelas $X I I$ (1st ed.). Andi Publisher.

Kementerian Koperasi dan Usaha Kecil dan Menengah. (2018). Perkembangan Data Usaha Mikro , Kecil, Menengah Dan Usaha Besar. In Www.Depkop.Go.Id.

Naidu, S., \& Chand, A. (2012). A comparative study of the financial problems faced by micro, small and medium enterprises in the manufacturing sector of Fiji and Tonga. International Journal of Emerging Markets, 7(3), 245262.

https://doi.org/10.1108/1746880 1211236974

Porras-Gómez, A. M. (2020). The control pyramid: A model of integrated public financial control. Financial Accountability and 
Management, 36(1), 73-89.

https://doi.org/10.1111/faam.12

221

Sudjana, D. (2007). Ilmu dan Aplikasi

Pendidikan: Bagian 4

Pendidikan Lintas Bidang (2nd ed.; W. rasyidin Muhammad ali, R. Ibrahim, Nana syaodih nukmadinata, Djudju sudjana, ed.). Jakarta: PT Imperial Bakti Utama.

Syarifah, A., \& Fauziyah, F. (2017). Pengaruh Adopsi Teknologi Informasi Pada Peningkatan Daya Saing Usaha Kecil Dan Menengah (Studi Pada UKM Di Wilayah Daerah Istimewa Yogyakarta). Jurnal Manajemen Bisnis, 8(2), 181-199.

Yoka Roida, H., Sunarjanto, N. A., \& Jayaprana, W. (2010). Internasionalisasi usaha mikro, kecil, dan menengah (umkm) ditinjau dari tipe kepemilikan: studi empiris di jawa timur. Jurnal Manajemen Teori Dan Terapan, 3(2), 158-170. 